Assiut Scientific Nursing Journal

http://asnj.journals.ekb.eg

http://www.arabimpactfactor.com

\title{
Knowledge and Attitudes of Health Care Team towards AIDs Patients at Assiut Fever Hospital
}

\author{
Mary H. Fakher ${ }^{1}$, Safaa R. Mahmoud ${ }^{2}$, Fatma R. Khalf ${ }^{3}$. \\ 1. Head Nurse of surveillance and epidemiology Assuit Fever Hospital, Egypt. \\ 2. Assistant Professor of Community Health Nursing Assiut University, Egypt. \\ 3. Lecturerof Community Health Nursing Assiut University, Egypt.
}

\begin{abstract}
Background: Health-care professionals occupy a potential forefront position in HIV/ AIDS prevention programs and the management of AIDS patients. Aim of the study: to assess knowledge and attitudes of health care team at Assiut Fever Hospital towards AIDs Patients. Material and Methods: A cross sectional study was conducted at Assiut Fever Hospital. A convenient sample of 202 of health care team participated in the study. Self-administered questionnaire used for data collection it include three sections; 1- socio-demographic characteristics. 2- Questions regarding knowledge about AIDs. 3- Attitudes of health care team towards AIDs Patients. Results: the study revealed that $66.3 \%$ of studied participants were females, $47 \%$ had ten years or more, $56.4 \%$ of the studied health care team had attending training about AIDs, while $73.3 \%$ of them are dealing with AIDS patients as a part of work. $44.6 \%$ of studied health care team had good knowledge about AIDS and $63.9 \%$ of them had negative attitude towards AIDS patients. Conclusions: Although the health care team had a good level of knowledge; they had negative attitudes towards AIDs Patients. Recommendation: Continuing in-service trainings on HIV/AIDS for health care team is needed.
\end{abstract}

\section{Keywords: AIDS, Attitudes, Health Care Team \& Knowledge.}

\section{Introduction}

Human Immunodeficiency Virus(HIV), is the virus that causes Acquired Immunodeficiency Syndrome (AIDS) first identified in 1981, HIV is the cause of one of humanity's deadliest and most persistent epidemics. Although significant progress has been made in the fight against new infections and AIDS deaths, the HIV pandemic continues around the world (Turkeltaub, et al., 2017).

Globally, in 2016, about 36.7 million people were living with HIV and it resulted in 1 million deaths (Unaids, 2017) .The Middle East and North Africa (MENA) region has HIV prevalence rate with 220,000 people recorded to be living with HIV in 2017. Almost two thirds of new HIV infections in 2017 were in Egypt, the Islamic Republic of Iran and Sudan (Unaids, 2018).

With less than 1 percent of the population estimated to be HIV-positive,prevalence rates of HIV in Egypt between the years 2006 and 2011 increased tenfold until2011; the average number of new cases of HIV in Egypt was 400 per year. But, in 2012 and 2013 it increased to about 600 new cases and in 2014 it reached 880 new cases per year (Unicef Egypt, 2017) According to UNAIDS 2016 statistics, there are about 11,000 people currently living with HIV in Egypt (Unaids, 2016).However, unsafe behaviors among most populations place Egypt at risk of a broader epidemic (Boutros \& Skordis, 2010).
The disease is transmitted through infected person who has sex partner more than one, semen, vaginal fluids, by using the infected drug needles, contaminated blood and mother to child transmission during pregnancy, birth and breast feeding. The infection doesn't transmit by casual contact (Hugging, kissing, mosquito, participation in sports and touching) (Hassan \& Wahsheh, 2011).

Unlike many other diseases, there is no cure or vaccine for AIDs; however, antiretroviral treatment can slow the progress of the disease and may lead to a near-normal life expectancy. Treatment is recommended as soon as the diagnosis is made. Without treatment, average survival time after infection with HIV is estimated to be 9 to 11 years (World Health Organization (WHO), 2015).

As the infection progresses, it interferes more with the immune system, increasing the risk of developing common infections such as tuberculosis, as well as other opportunistic infections, and tumors. These late symptoms of infection are referred to as acquired immunodeficiency syndrome (AIDS) (World Health Organization (WHO),2015).

In Egypt, There is a general reluctance on the part of the government and civil society to discuss issues related to marginalized groups such as MSM, FSWs, and IDUs. In some parts of Egyptian society, it is considered immoral to have HIV. Additionally, the mortality of people with HIV only seemed to justify 
the conservative society's view of homosexuality and promiscuity as sinful actions. These views further the cloud of stigma and shame associated with having HIV in Egypt and prevents people from utilizing the HIV testing services (Alkaiyat\& Weiss, 2013).

Health care workers (HCWs) especially nurses are at high risk of HIV/AIDS when they do not follow the standard precautions e.g. unsafe injection is the main risk of infection. That's why there is important to bring up to date the nurse's knowledge regarding nature of HIV/AIDS, prevention and treatment is essential to provide the better care (Lui, et al., 2014). Community health nurses as healthcare providers and community members are perform multiple functions in HIV programs, including referring community members for HIV testing, linking them to care, accompanying them to clinic appointments, providing psychosocial support, making referrals to other services and counseling (Thomson, et al., 2014).

\section{Significance of the study}

Health-care professionals occupy a potential forefront position in HIV/ AIDS prevention programs and the management of AIDS patients. An important factor fueling the spread of HIV/AIDS in developing countries is believed to be poor knowledge, perception, attitude, and practice about how the disease is spread and how it can be prevented (Unaids, 2016).

In some parts of Egyptian society, it is considered immoral to have HIV. Additionally, the mortality of people with HIV only seemed to justify the conservative society's view of homosexuality and promiscuity as sinful actions. These views further the cloud of stigma and shame associated with having HIV in Egypt and prevents people from utilizing the HIV testing services. In addition, there a lack of effective STI/HIV/AIDS education programs and other preventive measures, such as peer education, outreach work, and behavior change communications among at-risk groups. This stems from the lack of overall knowledge about the disease. According to recent studies, there is an imminent need for improved education of healthcare workers about HIV/AIDS in Egypt. (Alkaiyat \& Weiss, 2013)

\section{Aim of study}

This study aimed to:

1- Assess knowledge of health care team at Assiut Fever Hospital regarding AIDs disease.

2- Assess attitudes of health care team at Assiut Fever Hospital towards AIDs Patients.

\section{Research questions}

1. What is the level of knowledge about HIV/AIDS among health care team at Assiut Fever Hospital?
2. What are the attitudes of health care team at Assiut Fever Hospital towards patients with HIV/AIDS?

\section{Material \& Methods \\ Research design}

A descriptive cross-sectional research design was used in this study.

\section{Setting}

The study was carried out at Assiut Fever Hospital affiliated to Ministry of Health. And it has the National AIDS Program, which serves four governorates: Asyut, Red Sea, New Valley and Qena. Sample technique

The study included 202participantsof convenient selected HCWs. The sample divided as the following 128 nursing staff members,27head nurses, 25 physician, 2 dentists, 9 laboratory technicians and 11 X-ray technicians. The numbers of HCWs were successful complete the questionnaire represent $98 \%$ from total number of the health care team at Assiut Fever Hospital

\section{Tools of the study}

Self-administered questionnaire form was developed by the researcher for the collection of data. It was based on review of related literature. The questionnaire included three parts:

The first part: Personal characteristics as age, gender, marital status, educational level, occupation, years of experience, received previous training about AIDs, dealing with AIDS patients as part of their work

The second part: A modified Knowledge scale which developed by (Diclemente, et al, 1986) to assess knowledge of health care team regarding AIDs disease as definition, Characteristics , Causes, Presences, Mode of transmission, High risk group and Treatment/control of AIDS . It's consisted of 52 statements with response (Yes, No, Don't known).

\section{Scoring system of knowledge}

The correct response was score as "1," and the incorrect and "Don't know" responded as "0." An overall knowledge score was calculate by summing the scores for statements, thus the highest possible score was be 52 points then all summated and converted to percentage mean score.

Total scoring for knowledge was (52) grade. The correct response will score as " 1 ," and the incorrect and "Don't know" responses as " 0 ." . The score of each item summed-up and then converted into a percent score $($ poor $=$ score $<70 \%$, Fair $=$ score 70 $80 \%$, Good $=$ score $>80 \%$ ).

The third part: Attitude scale which adapted by (Gerbert, et al., 1991) and modified by (Hossain \& Kippax, 2011) to assess attitude of health care team towards AIDs patients. It included 16 statements 
consists of three points (Disagree, Uncertain and Agree).Items were scored $(2,1,0)$ respectively and disagree indicated positive attitudes.

\section{Scoring system of reported attitudes}

Regarding to total scoring for attitudes was (32) grade. Total score was calculated by summing-up and then converted into a percent score. Health care team attitude was considered positive if the score was $\geq$ $70 \%$ and negative attitude if the score was $<70 \%$ ).

Validity of tool: To evaluate the sheet validity. It was reviewed by five experts in nursing sciences to test the content validity.

\section{Methods}

\section{Administrative design}

Official approval letter was obtained from the Dean of Faculty of Nursing, Assiut University, Coordinator of the National AIDS Program at Directorate of Health Affairs in Assiut, Coordinator of the National AIDS Program at Assiut Fever Hospital, Director of Assiut Fever Hospital, Nursing Director, and Head of each department to collect the necessary data.

\section{Pilot Study}

It was conducted before the beginning of data collection on $10 \%$ of total sample number which were included in the total study sample because there weren't any modifications in the questionnaire.

\section{Field work}

The data collection was started from the end of January to the end of June 2019. After explaining the purpose of the study.The average of time taken for completing each sheet took about (15-20) minutes depending on the persons' response to questions, followed by correction and explanation for every wrong answer. The data was collected at Saturday and Sunday at morning shift /week. About (3-5)sheet was finished daily.

\section{Ethical consideration}

The study was approved by the ethical committee in the Faculty of Nursing, Assiut University. Verbal consent was obtained from all participants. Study participants' privacy and confidentiality were considered during collection of the data. Participants had the right to withdraw from the study at any time and without any rational.

\section{Statistical analysis}

Data entry and data analysis were done using the IBM SPSS, version 20 (Statistical Package for Social Science). Categorical variables were described by number and percentage (No., \%) while continuous variables described by mean and standard deviation (Mean \pm SD).Chi-square test was used to compare differences in the distribution of frequencies between different groups. A $\mathrm{p}$ value $<0.05$ was considered statistically significant. 


\section{Results}

Table (1): Personal characteristics of studied health care team at AssiutFever Hospital 2019:

\begin{tabular}{|c|c|c|}
\hline Variables & No. $(n=202)$ & $\%$ \\
\hline \multicolumn{3}{|l|}{ Age: (years) } \\
\hline$<30$ & 92 & 45.5 \\
\hline $30-40$ & 51 & 25.3 \\
\hline$>40$ & 59 & 29.2 \\
\hline Mean \pm SD (Range) & \multicolumn{2}{|c|}{$34.61 \pm 10.57(21.0-60.0)$} \\
\hline \multicolumn{3}{|l|}{ Marital status: } \\
\hline Single & 54 & 26.7 \\
\hline Married & 144 & 71.3 \\
\hline Divorced & 2 & 1.0 \\
\hline Widow & 2 & 1.0 \\
\hline \multicolumn{3}{|l|}{ Occupation } \\
\hline Physician & 25 & $12.4 \%$ \\
\hline Dentist & 2 & $1 \%$ \\
\hline Head nurse & 27 & 13.4 \\
\hline Nurse & 128 & 63.4 \\
\hline Lab technician & 9 & 4.5 \\
\hline X-ray technician & 11 & 5.4 \\
\hline \multicolumn{3}{|l|}{ Education: } \\
\hline Secondary school & 65 & 32.2 \\
\hline Technical institute & 83 & 41.1 \\
\hline University- post graduate & 54 & 26.7 \\
\hline \multicolumn{3}{|l|}{ Experience: } \\
\hline$<1$ year & 19 & 9.4 \\
\hline $1-<5$ years & 57 & 28.2 \\
\hline $5-<10$ & 31 & 15.3 \\
\hline$\geq 10$ & 95 & 47.0 \\
\hline \multicolumn{3}{|l|}{ Attending training about AIDs: } \\
\hline Yes & 114 & 56.4 \\
\hline No & 88 & 43.6 \\
\hline \multicolumn{3}{|c|}{ Dealing with AIDS patients as a part of work: } \\
\hline Yes & 148 & 73.3 \\
\hline No & 54 & 26.7 \\
\hline
\end{tabular}

Table (2): Knowledge of studied health care team about AIDs at AssiutFever Hospital, 2019:

\begin{tabular}{|l|c|c|}
\hline \multicolumn{1}{|c|}{ Variables } & Correct answer \\
\cline { 2 - 3 } \multicolumn{1}{|c|}{} & No. & \% \\
\hline Definition of AIDS & & \\
\hline AIDs is a disease that affects the human immune system and is produced mainly by HIV. & 199 & 98.5 \\
\hline Characteristics of AIDS & & \\
\hline People with AIDs usually have a lot of other disease as a result of AIDs. & 189 & 93.6 \\
\hline A person can be infected with HIV and not have AIDS. & 87 & 43.1 \\
\hline Causes of AIDs & & \\
\hline AIDs is caused by a virus. & 193 & 95.5 \\
\hline AIDs is caused by the same virus that cause sexually transmitted diseases. & 76 & 37.6 \\
\hline Presences of HIV & & \\
\hline Blood of infected person. & 199 & 98.5 \\
\hline Saliva of infected person. & 99 & 49 \\
\hline Mode of transmission of AIDs & & \\
\hline
\end{tabular}




\begin{tabular}{|c|c|c|}
\hline \multirow{2}{*}{ Variables } & \multicolumn{2}{|c|}{ Correct answer } \\
\hline & No. & $\%$ \\
\hline Sharing needle with a drug user who has a disease. & 199 & 98.5 \\
\hline If you donated blood you can get AIDs. & 87 & 43.1 \\
\hline \multicolumn{3}{|l|}{ High risk group } \\
\hline Drug addicts are at high risk to AIDs. & 199 & 98.5 \\
\hline Patients in hospitals are at high risk to AIDs. & 85 & 42.1 \\
\hline \multicolumn{3}{|l|}{ Treatment/control of AIDS } \\
\hline A new vaccine has recently been developed for the treatment of AIDS. & 127 & 62.9 \\
\hline You can avoid getting AIDS by following universal precautions. & 179 & 88.6 \\
\hline
\end{tabular}

Table (3): Relationship between total score of studied health care team knowledge about AIDS and their personal characteristics at AssiutFever Hospital, 2019:

\begin{tabular}{|c|c|c|c|c|c|c|c|}
\hline \multirow{3}{*}{ Variables } & \multicolumn{6}{|c|}{ Knowledge level } & \multirow{3}{*}{ P-value } \\
\hline & \multicolumn{2}{|c|}{$\begin{array}{c}\text { Poor } \\
(n=42)\end{array}$} & \multicolumn{2}{|c|}{$\begin{array}{c}\text { Fair } \\
(n=70)\end{array}$} & \multicolumn{2}{|c|}{$\begin{array}{c}\text { Good } \\
(n=90)\end{array}$} & \\
\hline & No. & $\%$ & No. & $\%$ & No. & $\%$ & \\
\hline Age: (years) & & & & & & & \multirow{4}{*}{0.121} \\
\hline$<30$ & 23 & 25.0 & 34 & 37.0 & 35 & 38.0 & \\
\hline $30-40$ & 9 & 17.6 & 12 & 23.5 & 30 & 58.8 & \\
\hline$>40$ & 10 & 16.9 & 24 & 40.7 & 25 & 42.4 & \\
\hline \multicolumn{7}{|l|}{ Gender: } & \multirow{3}{*}{0.366} \\
\hline Male & 12 & 17.6 & 28 & 41.2 & 28 & 41.2 & \\
\hline Female & 30 & 22.4 & 42 & 31.3 & 62 & 46.3 & \\
\hline \multicolumn{7}{|l|}{ Marital status: } & \multirow{3}{*}{0.192} \\
\hline Single & 15 & 27.8 & 20 & 37.0 & 19 & 35.2 & \\
\hline Ever-married & 27 & 18.2 & 50 & 33.8 & 71 & 48.0 & \\
\hline \multicolumn{7}{|l|}{ Education: } & \multirow{4}{*}{0.199} \\
\hline Secondary school & 11 & 16.9 & 23 & 35.4 & 31 & 47.7 & \\
\hline Technical institute & 23 & 27.7 & 30 & 36.1 & 30 & 36.1 & \\
\hline University & 8 & 14.8 & 17 & 31.5 & 29 & 53.7 & \\
\hline \multicolumn{7}{|l|}{ Occupation: } & \multirow{5}{*}{0.129} \\
\hline Physician/ dentist & 2 & 7.4 & 8 & 29.6 & 17 & 63.0 & \\
\hline Head nurse & 6 & 22.2 & 9 & 33.3 & 12 & 44.4 & \\
\hline Nurse & 27 & 21.1 & 44 & 34.4 & 57 & 44.5 & \\
\hline Lab/ x-ray technician & 7 & 35.0 & 9 & 45.0 & 4 & 20.0 & \\
\hline \multicolumn{7}{|l|}{ Experience:(years) } & \multirow{5}{*}{0.174} \\
\hline$<1$ & 8 & 42.1 & 9 & 47.4 & 2 & 10.5 & \\
\hline $1-<5$ & 12 & 21.1 & 18 & 31.6 & 27 & 47.4 & \\
\hline $5-<10$ & 5 & 16.1 & 10 & 32.3 & 16 & 51.6 & \\
\hline$\geq 10$ & 17 & 17.9 & 33 & 34.7 & 45 & 47.4 & \\
\hline \multicolumn{7}{|c|}{ Attending training about AIDs: } & \multirow{3}{*}{$0.000^{*}$} \\
\hline Yes & 20 & 17.5 & 27 & 23.7 & 67 & 58.8 & \\
\hline No & 22 & 25 & 43 & 48.9 & 23 & 26.1 & \\
\hline \multicolumn{7}{|c|}{ Dealing with AIDS patients as a part of work: } & \\
\hline Yes & 14 & 9.5 & 64 & 43.2 & 70 & 47.3 & \multirow{2}{*}{$0.000^{*}$} \\
\hline No & 28 & 51.9 & 6 & 11.1 & 20 & 37.0 & \\
\hline
\end{tabular}


Table (4): Attitude of studied health care team towards AIDs patients at Assiut Fever Hospital, 2019.

\begin{tabular}{|l|c|c|c|c|c|c|}
\hline \multicolumn{1}{|c|}{ Variables } & \multicolumn{2}{|c|}{ Agree } & \multicolumn{2}{c|}{ Disagree } & \multicolumn{2}{c|}{ Uncertain } \\
\cline { 2 - 7 } & No. & $\%$ & No. & \% & No. & $\%$ \\
\hline $\begin{array}{l}\text { Patients with HIV and AIDS should not be allowed to mix } \\
\text { freely with other people }\end{array}$ & 126 & 62.4 & 69 & 34.2 & 7 & 3.5 \\
\hline $\begin{array}{l}\text { I prefer to refer persons with HIV and AIDS to other } \\
\text { physicians/ care providers }\end{array}$ & 113 & 55.9 & 74 & 36.6 & 15 & 7.4 \\
\hline $\begin{array}{l}\text { I do not want to deal with infected persons with HIV and } \\
\text { AIDS }\end{array}$ & 119 & 58.9 & 72 & 35.6 & 11 & 5.4 \\
\hline $\begin{array}{l}\text { Children with HIV and AIDS should not be allowed to attend } \\
\text { public schools }\end{array}$ & 145 & 71.8 & 50 & 24.8 & 7 & 3.5 \\
\hline If I had a choice, I would not work with HIV/AIDS patients & 138 & 68.3 & 57 & 28.2 & 7 & 3.5 \\
\hline $\begin{array}{l}\text { People who have HIV and AIDS should not be allowed to } \\
\text { work }\end{array}$ & 147 & 72.8 & 45 & 22.3 & 10 & 5.0 \\
\hline $\begin{array}{l}\text { Patients with HIV and AIDS should be forced to resign from } \\
\text { their job }\end{array}$ & 190 & 94.1 & 7 & 3.5 & 5 & 2.5 \\
\hline I do not welcome to infected person in my department & 163 & 80.7 & 34 & 16.8 & 5 & 2.5 \\
\hline Needs of people with HIV should not be given priority & 161 & 79.7 & 31 & 15.3 & 10 & 5.0 \\
\hline $\begin{array}{l}\text { I will not feel comfort if my other patients knew that I treated } \\
\text { people with HIV and AIDS }\end{array}$ & 119 & 58.9 & 77 & 38.1 & 6 & 3.0 \\
\hline $\begin{array}{l}\text { I will request my authority to exclude me from the } \\
\text { responsibility of caring PLHIV }\end{array}$ & 171 & 84.7 & 25 & 12.4 & 6 & 3.0 \\
\hline $\begin{array}{l}\text { I will not feel comfort if other physicians knew that I treated } \\
\text { people with HIV and AIDS }\end{array}$ & 147 & 72.8 & 45 & 22.3 & 10 & 5.0 \\
\hline $\begin{array}{l}\text { Medical students who are HIV-positive should not have the } \\
\text { right to complete their study }\end{array}$ & 157 & 77.7 & 36 & 17.8 & 9 & 4.5 \\
\hline $\begin{array}{l}\text { Government should spend less money on HIV and AIDS, } \\
\text { and more on other more common diseases }\end{array}$ & 135 & 66.8 & 64 & 31.7 & 3 & 1.5 \\
\hline $\begin{array}{l}\text { Our country does not need any laws to protect people with } \\
\text { HIV and AIDS from discrimination }\end{array}$ & 147 & 72.8 & 45 & 22.3 & 10 & 5.0 \\
\hline $\begin{array}{l}\text { I do not have a responsibility to treat people with HIV and } \\
\text { AIDS }\end{array}$ & 150 & 74.3 & 43 & 21.3 & 9 & 4.5 \\
\hline
\end{tabular}

Table (5): Relationship between total score of studied health care team attitude towards AIDS patients and their personal characteristics at Assiut Fever Hospital, 2019.

\begin{tabular}{|c|c|c|c|c|c|}
\hline \multirow{3}{*}{ Variables } & \multicolumn{4}{|c|}{ Attitude level } & \multirow{3}{*}{ P-value } \\
\hline & \multicolumn{2}{|c|}{ Positive (n= 73) } & \multicolumn{2}{|c|}{ Negative $(n=129)$} & \\
\hline & No. & $\%$ & No. & $\%$ & \\
\hline \multicolumn{5}{|l|}{ Age: (years) } & \multirow{4}{*}{$0.020^{*}$} \\
\hline$<30$ & 27 & 29.3 & 65 & 70.7 & \\
\hline $30-40$ & 16 & 31.4 & 35 & 68.6 & \\
\hline$>40$ & 30 & 50.8 & 29 & 49.2 & \\
\hline \multicolumn{5}{|l|}{ Gender } & \multirow{3}{*}{$0.046^{*}$} \\
\hline Male & 31 & 45.6 & 37 & 54.4 & \\
\hline Female & 42 & 31.3 & 92 & 68.7 & \\
\hline \multicolumn{5}{|l|}{ Marital status: } & \multirow{3}{*}{0.135} \\
\hline Single & 15 & 27.8 & 39 & 72.2 & \\
\hline Ever-married & 58 & 39.2 & 90 & 60.8 & \\
\hline \multicolumn{5}{|l|}{ Education: } & \multirow{4}{*}{0.095} \\
\hline Secondary school & 27 & 41.5 & 38 & 58.5 & \\
\hline Technical institute & 33 & 39.8 & 50 & 60.2 & \\
\hline University & 13 & 24.1 & 41 & 75.9 & \\
\hline
\end{tabular}




\begin{tabular}{|c|c|c|c|c|c|}
\hline \multirow{3}{*}{ Variables } & \multicolumn{4}{|c|}{ Attitude level } & \multirow{3}{*}{ P-value } \\
\hline & \multicolumn{2}{|c|}{ Positive $(n=73)$} & \multicolumn{2}{|c|}{ Negative $(n=129)$} & \\
\hline & No. & $\%$ & No. & $\%$ & \\
\hline Occupation: & & & & & \multirow{5}{*}{0.058} \\
\hline Physician/ dentist & 8 & 29.6 & 19 & 70.4 & \\
\hline Head nurse & 5 & 18.5 & 22 & 81.5 & \\
\hline Nurse & 49 & 38.3 & 79 & 61.7 & \\
\hline Lab/ x-ray technician & 11 & 55.0 & 9 & 45.0 & \\
\hline \multicolumn{5}{|c|}{ Attending training about AIDs: } & \multirow{3}{*}{0.408} \\
\hline Yes & 44 & 38.6 & 70 & 61.4 & \\
\hline No & 29 & 33.0 & 59 & 67.0 & \\
\hline \multicolumn{5}{|c|}{$\begin{array}{l}\text { Dealing with AIDS patients as a part } \\
\text { of work: }\end{array}$} & \multirow{3}{*}{0.623} \\
\hline Yes & 52 & 35.1 & 96 & 64.9 & \\
\hline No & 21 & 38.9 & 33 & 61.1 & \\
\hline
\end{tabular}

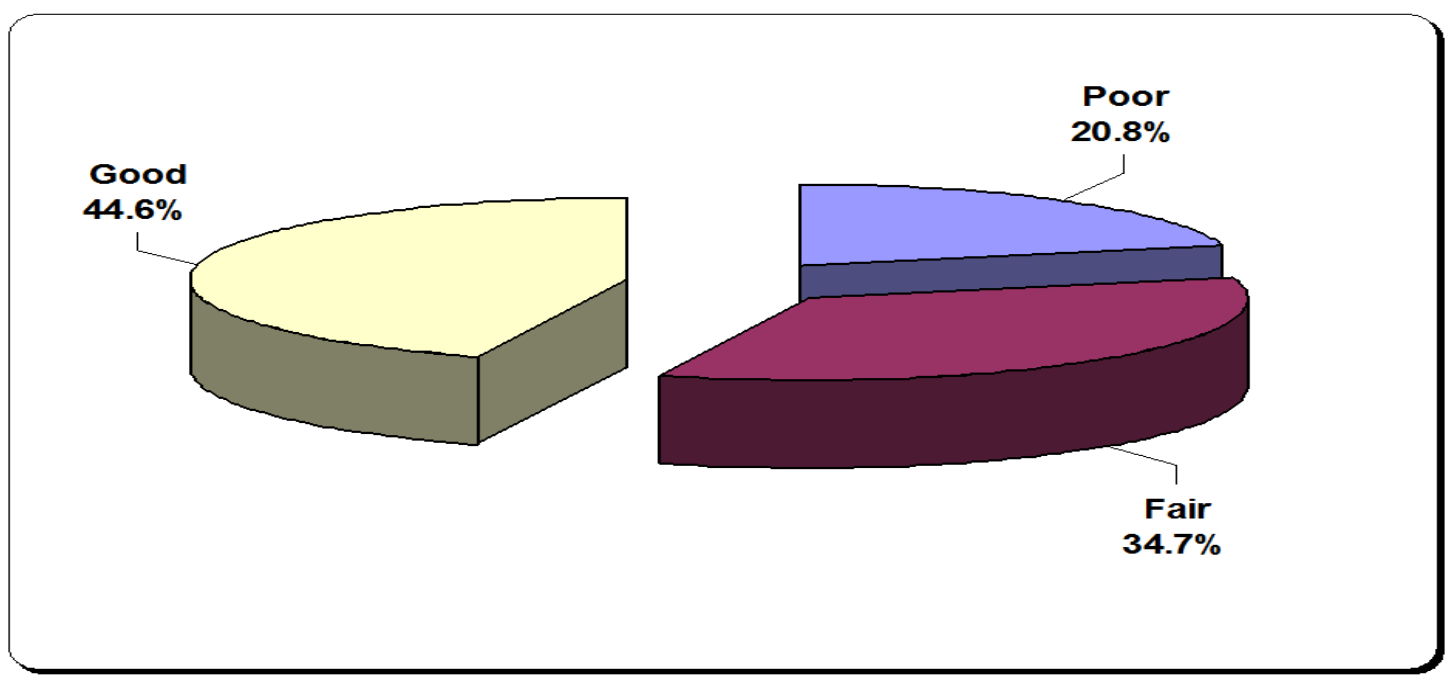

Fig (1): Distributions of studied health team regarding their total score of knowledge about AIDS at Assiut Fever Hospital 2019.

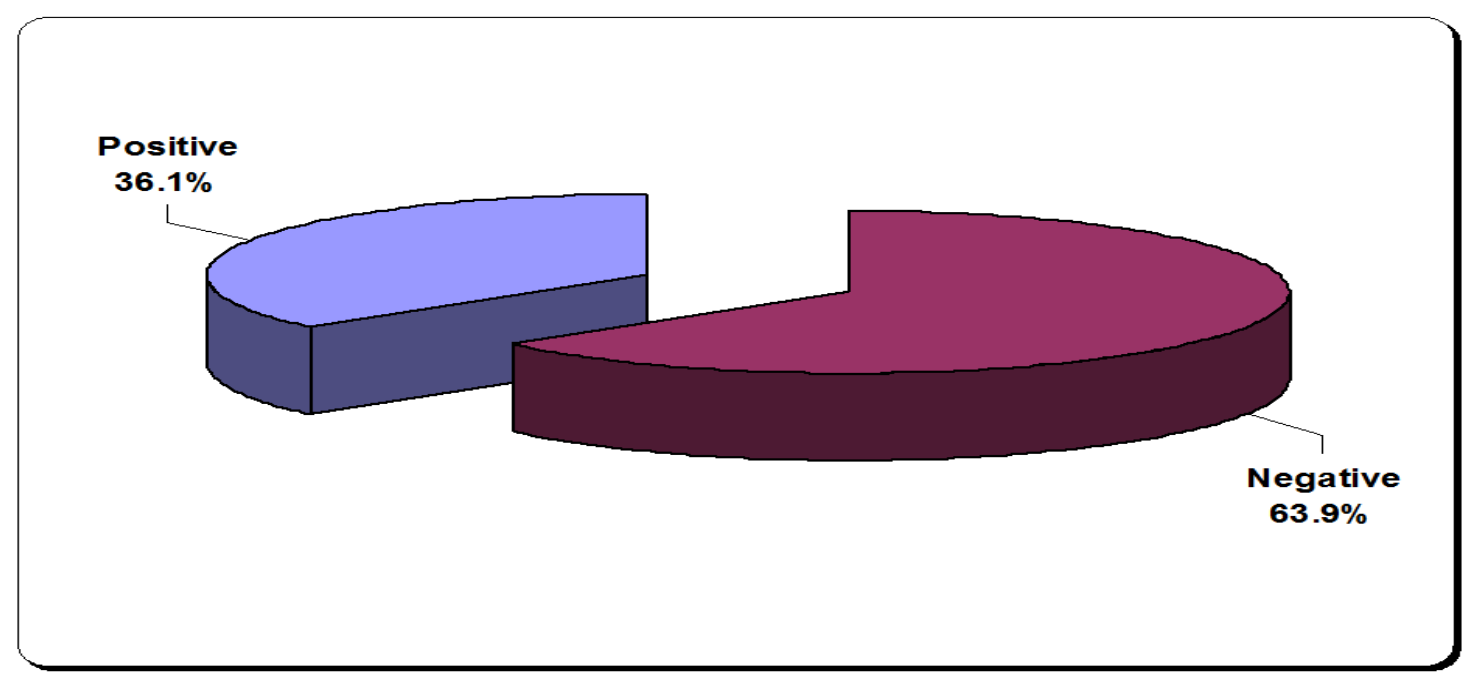

Fig (2): Distributions of studied health team regarding their attitudes score towards AIDS patients at Assiut Fever Hospital 2019. 


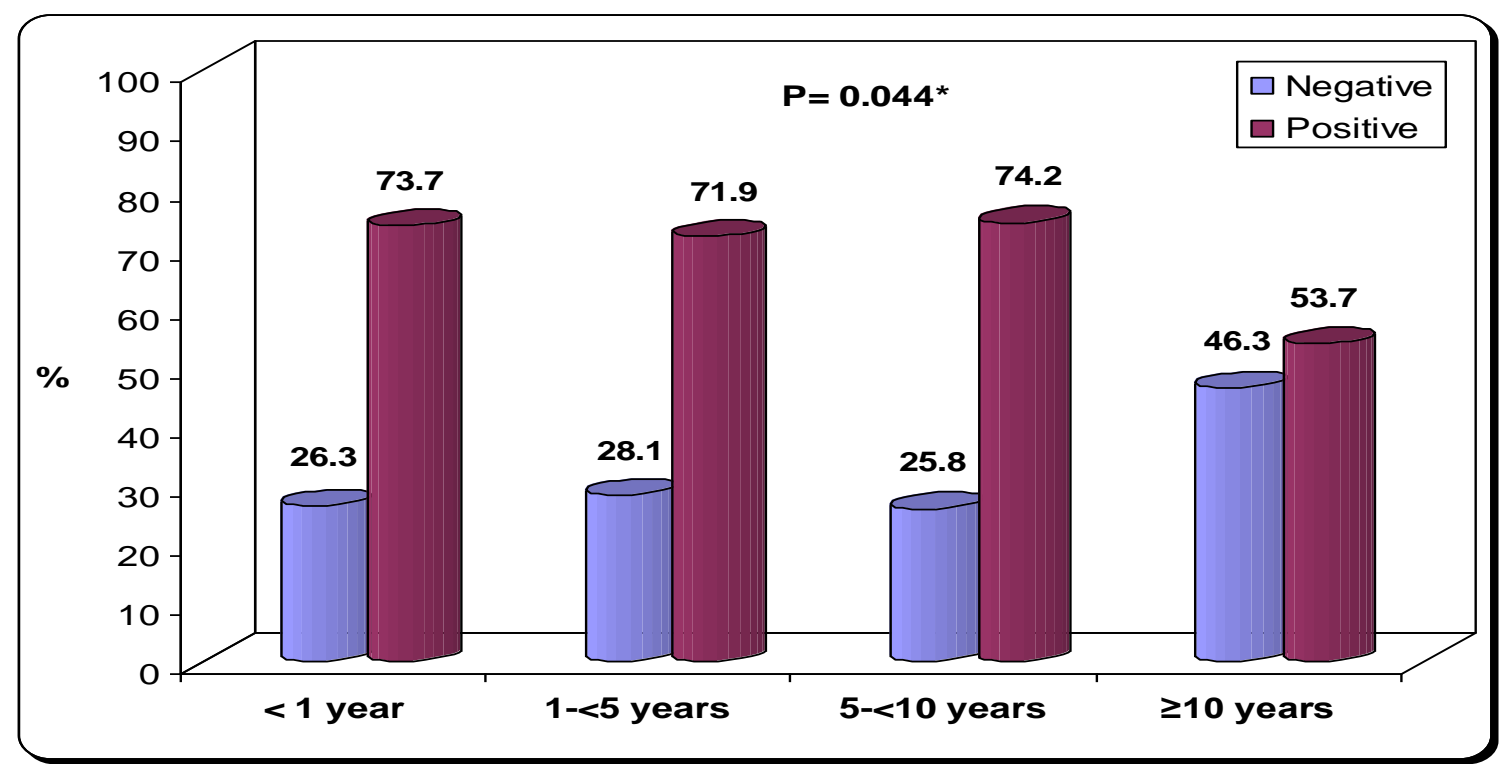

Fig. (3): Relationship between studied health care team years of experience and their total score of attitude towards AIDS patients at Assiut Fever Hospital 2019

Table (1): Showed that $45.5 \%$ of the studied health care team aged less than 30 year, Regarding marital status it was $71.3 \%$ of the studied health care team were married and $41.1 \%$ of them had technical institute education, Concerning occupation showed that $63.4 \%$ of studied health care team were nurses while $12.4 \%$ were physician, the others were head nurse, $\mathrm{x}$-ray technicians, laboratory technicians, dentist were $(13.4 \%, 5.4 \%$ and $4.5 \%)$ respectively, Regarding job experience found that $47 \%$ had ten years or more, $56.4 \%$ of the studied health care team had attending training about AIDs, while $73.3 \%$ of them are dealing with AIDS patients as a part of work.

Table (2): Illustrated knowledge of the studied health care team towards AIDs. $98.5 \%$ of studied health care team had known the correct definition of AIDs while 93.6\% of studied health care team reported that people with AIDs usually have a lot of other disease as a result of AIDs. Also, this table showed that $95.5 \%$ of the studied health care team reported AIDs is caused by a virus, $37.6 \%$ of them reported that AIDs is caused by the same virus that cause sexually transmitted diseases and $98.5 \%$ of studied health care team stated that HIV can be found in infected person in blood while $53 \%$ of them reported that donated blood they can get AIDs. In additional to $71.8 \%$ of studied health care team believed that health care provider are at high risk to AIDs while $88.6 \%$ of them reported that they can avoid getting AIDS by following universal precautions.

Table (3): Showed that there was statistical significant difference were found between health care team who attending training about AIDs and health care team who dealing with AIDS patients as a part of work. P.value $(0.000,0.000)$ respectively.

Table (4): Illustrates attitudes of studied health care team towards AIDs patients which studied healthcare team had negative attitudes towards patients with HIV and AIDS where (94.1\%) of them agreedonthese patients should be forced to resign from their job, $(84.7 \%)$ of studied sample agreed on will request their authority to exclude them from the responsibility of caring People Live with HIV, (80.7\%)of them didn't agreed on welcome to infected person in there department, (79.7\%) didn't agreed on given priority for needs of people with HIV.

Table (5): There was statistical significant difference relation between age, gender and attitudes of studied health care team regarding AIDS.

Fig (1): It showed that $44.6 \%$ of studied health care team had good knowledge about AIDS.

Fig (2): This figure illustrated that $63.9 \%$ of the studied healthcare team had negative attitude towards AIDS patients.

Fig (3): Relationship between studied health care team years of experience and their total score of attitude towards AIDS patients. It showed that there was statistical significant difference between years of experience of health care team and their total score of attitude towards AIDS patients. P.value (0.044)

\section{Discussion}

By the end of 1986 the Ministry of health in Egypt reported the first HIV/AIDS case, since that time there is a steady increase in people living with HIV number in Egypt. This steady increase is expected with the advent of counseling and testing services in 
different settings and with the expansion of the awareness activities to focus more on reaching those at risk in different governorates .Scaling up the surveillance system and giving more attention to the care and support services provided to People Live With HIV, all these factors give a strong indicator of increasing epidemic .People requiring care and support are thus on the rise. Accordingly, AIDS will become a public health problem of primary importance as health of one individual affects all the community. (WHO, 2015)

The present study has been aimed to assess knowledge and attitudes of health care team towards AIDs patients at Assiut Fever Hospital. The findings of the present study showed that the mean age of participants was $(\mathbf{3 4 . 6 1 \pm 1 0 . 5 7 )}$ and these findings were similar to Vorasane, et al., (2017) who carried out a study to assess an investigation of stigmatizing attitudes towards people living with HIV/AIDS by doctors and nurses in Vientiane and found that the mean age of their participants was $(37 \pm 10.1)$.

In relation to the gender of the participants the current study revealed that more than three fifths of participants were females and more than one fifth were males. That might explained by the majority of health care team at Assiut Fever Hospital were females, and that is because the largest number of the sample is nurses, and most graduates of nursing schools and the faculty of Nursing are female.

This study similar with Mtengezo, et al., (2016) who carried out study among health-care workers in Malawi and found that female were $63.4 \%$ and male were $36.6 \%$.

These results disagree with Al-Salihy \& Enad, (2017) who carried out a study to assess knowledge and attitude of health care workers in Baquba Teaching Hospital(Iraq) toward HIV/AIDS infection and reported that males more than females.

According to the definition of the AIDS, the present study indicated that the vast majority of studied participants knew the correct definition of it. That might explained by this group studied AIDs in their curriculums in the past.

This study in the same line with Chen \& Han, (2010)who carried out a study to evaluate the Chinese nurses knowledge and attitudes regarding AIDs and reported that the majority of this study participants said that AIDS is caused by a virus that damages the human immune system.
In respect to Knowledge related the characteristics of AIDS; was demonstrated that less than three quarter of participants mentioned that women are more likely to have not AIDS during their menstruation. That might attributed by they knew that menstrual blood does not cause infection or protection from it.

This study similar with Mtengezo, et al., (2016) who found that slightly less than majority of participants reported that a woman cannot get HIV if she has sex during her period.

According to the causes of AIDs; the vast majority of HCWs knew that AIDs is caused by a virus. That might explain by they linking any disease can transmit through blood is a virus as virus $\mathrm{C}$ and $\mathrm{B}$. These results supported by Al-Salihy \& Enad, (2017) who reported that the vast majority of respondents reported that the cause of AIDs is a virus.

According to presences of HIV, the current research it was revealed that less than half of studied participants said that HIV not found in saliva of infected person. That might interpreted by that they understand that the body fluid not included the saliva.

This study appropriated with Koç, et al., (2017) who carried out a study including Turkish nurses and informed that more than half of respondents informed that saliva isn't from HIV-containing body fluids.

As regards to the mode of transmission of AIDs; the majority of the studied participants reported that kissing someone with AIDs will not get the disease. It might attributed by they realized that external contact without exposure to body fluids does not cause infection.

This result disagreed with Alzahrani, et al., (2019) who carried out study among health care workers in southwestern Saudi Arabia and exposed that less than two thirds of studied sample explored that HIV can't transmitted by kissing with HIV infected person.

Also, this result showed that the vast majority of studied participants reported that casual contacts as touching with infected person can't transmit infection. It is might interpreted by that they know superficial contacts with infected person without contact anybody secretions can't transmitted AIDs.

These results agreed with Taher \& Abdelhai, (2011) who exposed the majority of respondents reported that touching person living with HIV can't transmitted AIDs.

On other hand this result opposed with (Chen \& Han, 2010) who found that only $(10.7 \%)$ of studied participants had known that casual contacts can't transmitted AIDs.

As regarding to the groups at high risk to AIDs, in the current study it was demonstrated that the vast majority of studied participants reported that drug addicts are at high risk to AIDs. It is attributed by that 
medical and nursing team aware that sharing needle is one of the main methods of mode of transmission.

This study similar with Hasani, et al., (2010) who carried out a cross sectional study among Iranian nurses and determined that the vast majority of studied sample reported that intravenous drug abusers are considered to be at risk for contracting HIV/AIDS.

Concerning to treatment and control of AIDS; the majority of the studied participants informed that AIDS can't be cured. It might explained by that health team know PLWHA non-stop to received treatment for ever.

These results agreed with Al-Salihy \& Enad, (2017) who found the majority of their studied respondents mentioned the similar attribution that AIDS isn't curable.

In the present study it was noticed that slightly two third of studied participants had a negative attitudes towards AIDs patients. That might suggested by the current negative attitudes of health care workers toward people with HIV - compounded by fear of infection in the workplace, perceptions of risk, lack of understanding of HIV and inconsistent universal precautions adherence - perpetuate the prevalence and manifestation of stigma toward this population.

In the current data it was appeared that less than two third of studied participants agreed with that HIV and AIDS people should not be allowed to mix freely with other people. That might interpreted by HCWs know that this disease is dangerous and infectious.

These finding were disagreed with Mtengezo, et al., (2016) who reported that the vast majority of their studied respondents agreed that a person living with HIV/AIDs or HCV or HBV should be isolated. In the current data it was appeared that less than two third of studied participants agreed with that HIV and AIDS people should not be allowed to mix freely with other people. That might interpreted by HCWs know that this disease is dangerous and infectious.

These finding were disagreed with Mtengezo, et al., (2016)who reported that the vast majority of their studied respondents agreed that person living with HIV/AIDs or HCV or HBV should be isolated.

In Egypt, these finding similar with Kabbash, et al., (2018) who carried out study among health care workers at Tanta University Hospitals, Egypt and showed that they had high levels of stigma and discrimination against PLHIV and Infection control is defective in the supplies and procedures.

Internationally, This finding similar with Hafeez, et al., (2017) who carried out study among health care providers working at tertiary care hospitals of Lahore, Pakistan and showed that there is no significant relationship between knowledge and attitude of healthcare provider toward HIV/AIDS where the knowledge does not affect the attitude as doctors have high knowledge, but they have biased attitude mainly with contamination.

\section{Conclusions}

Although the overall general knowledge about the diseases was considered to be good among the studied participants, there are some misconceptions about HIV/AIDS were detection and most studied participants showed negative attitudes at the study.

\section{Recommendation}

1. Continuing in-service trainings on HIV/AIDS for health care team is needed.

2. Further research should be done regarding AIDS to promote attitudes of $\mathrm{HCWs}$ and decrease the stigma.

3. Stigma-reduction programs among health care workers are urgently needed to improve the quality of provided care, uphold the human rights to healthcare, increase access to health care services, and maximize investments in HIV prevention and treatment.

\section{References}

1. Alkaiyat A., \&Weiss M., (2013): "HIV in the Middle East and North Africa: priority, culture, and control". International journal of public health, 58(6), 927-937.

2. -Al-Salihy S., \&Enad O., (2017): Knowledge and attitude of health care workers in Baquba Teaching Hospital toward HIV/AIDS infection .Iraqi Journal of Public Health , 1(2), 42-46.

3. Alzahrani H., Awadalla N., Hadi R., AlTameem F., Alkhayri M., Mosheba, A., Alqarni A., Al-Salateen F., Alqahtani A., \& Mahfouz A., (2019): Knowledge, Attitude and Practice of Health Care Workers towards HIV Patients at Primary Health Care level in southwestern Saudi Arabia: Twenty-five years after the initial report. Middle East Journal of Family Medicine, 17(6).

4. Boutros S., \&Skordis J., (2010): HIV/AIDS surveillance in egypt: Current status and future challenges

.EasternMediterraneanHealthJournal,16(3),251 8.Retrievedfromhttps://search.proquest.com/do cview/503279561 ?accountid $=15172$

5. Chen W., \& Han M., (2010): Knowledge, attitudes, perceived vulnerability of Chinese nurses and their preferences for caring for HIV-positive individuals: a cross-sectional survey. Journal of clinical nursing, 19(21-22), 3227-3234.

6. -Diclemente, R., Zorn, J., Temoshok, L., (1986): Adolescents and AIDS: A survey of 
knowledge, attitudes and beliefs about AIDS in San Francisco. American Journal of Public Health, 76, 1443-1445

7. Gerbert B., Maguire B., Bleecker T., Coates T., McPhee S., (1991): Primary care physicians and AIDS. Attitudinal andstructural barriers to care. JAMA;266:2837-42.

8. Hafeez T., Riaz S., Ali I., \& Irum N., (2017): A study of knowledge and attitude of health care providers working at tertiary care hospitals of Lahore, Pakistan (having HIV/AIDS treatment facility) towards HIV/AIDS. Acta Medica International 2017, Volume 4(1):124-31

9. Hasani A., Aghamolaei T., Tavafian S., \& Sabili A,(2010): Knowledge of Iranian nurses about HIV/AIDS: A cross sectional study from Bandar. Iranian Journal of Clinical Infectious Disease 2010;5(3):161-165

10. Hassan Z., \& Wahsheh M., (2011): Knowledge and Attitudes of Jordanian Nurses towards Patients with HIV/AIDS: Findings from a Nationwide Survey. Issues in Mental Health Nursing, 32(12),774-784

11. Hossain M., \& Kippax S., (2011): Stigmatized attitudes towards people living with HIV in Bangladesh: Health Care Workers' perspective. Asia Pacific Journal of Public Health, 23(2), 171-182.

12. Kabbash I., Ali E., Elgendy M., Abdrabo M., Salem H., Gouda M., Elbasiony Y., Elboshy N., \& Hamed, M., (2018): HIV/AIDS-related stigma and discrimination among health care workers at Tanta University Hospitals, Egypt. Environmental Science and Pollution Research, 25(31), 30755-30762

13. Koç A., Öztaş D and Ceylan E,(2017): Correlation of misperceptions in Turkish nurses' knowledge regarding HIV and their attitude toward patients with HIV/ AIDS. Medical Journal of Islamic World Academy of Sciences, 109(5646), 1-8.

14. Lui P., Sarangapany J., Begley K., Coote K., \& Kishore K., (2014): Medical and nursing students perceived knowledge, attitudes, and practices concerning human immunodeficiency virus. ISRN Public Health, 2014.

15. Mtengezo J., Lee H., Ngoma J., Kim S., Aronowitz T., DeMarco R., \& Shi L., (2016): Knowledge and attitudes toward HIV, hepatitis $\mathrm{B}$ virus, and hepatitis $\mathrm{C}$ virus infection among health-care workers in
Malawi. Asia-Pacific journal of oncology nursing, 3(4), 344.

16. Taher E., \&Abdelhai R., (2011): Nurses' knowledge, perceptions, and attitudes towards HIV/AIDS: Effects of a health education intervention on two nursing groups in Cairo University, Egypt. Journal of Public Health and Epidemiology, 3(4), 144-154.

17. Thomson D., Rich M., Kaigamba F., Socci A., Hakizamungu M., Bagiruwigize E., Binagwaho A., \& Franke M., (2014): Community-based accompaniment and psychosocial health outcomes in HIV-infected adults in Rwanda: a prospective study. AIDS and Behavior, 18(2), 368-380.

18. Turkeltaub A., Kollipara R., \&Tyring S., (2017): Life-threatening cutaneous viral diseases. Emergency Dermatology, 114.

19. Unaids (2016): "Country Factsheets: EGYPT 2016"https://en.wikipedia.org/wiki/HIV/AIDS _in_Egypt

20. -Unaids (2017): "Fact sheet - Latest statistics on the status of the AIDS epidemic ". Www.unaids.org. Archived from the original on July 13, 2017.

21. Unaids (2018):Global Factsheets"HIV and AIDS

Estimates'https://www.avert.org/professionals/ hiv-around-world/middle-east-north-africamena

22. Unicef Egypt -HIV/AIDS-Context,(2017): www.unicef.org. Retrieved 2017-11-08

23. Vorasane S., Jimba M., Kikuchi K., Yasuoka J., Nanishi K., Durham J., \& Sychareun V., (2017): An investigation of stigmatizing attitudes towards people living with HIV/AIDS by doctors and nurses in Vientiane, Lao PDR. BMC Health services research, 17(1), 125.

24.-World Health Organization, (2015) :Guideline on when to start antiretroviral therapy and on pre-exposure prophylaxis for HIV (PDF). WHO. 2015. p. 13. ISBN978-924-150956-5. Archived (PDF)from the original on October 14, 2015. 